\title{
Methodiek schoolverlatersinformatiesysteem 2004 en 2005
}

Citation for published version (APA):

Huijgen, T. G., \& van der Kolk, P. (2007). Methodiek schoolverlatersinformatiesysteem 2004 en 2005.

Researchcentrum voor Onderwijs en Arbeidsmarkt, Faculteit der Economische Wetenschappen. ROA

Working Papers No. 2 https://doi.org/10.26481/umarow.2007002

Document status and date:

Published: 01/01/2007

DOI:

10.26481/umarow.2007002

Document Version:

Publisher's PDF, also known as Version of record

\section{Please check the document version of this publication:}

- A submitted manuscript is the version of the article upon submission and before peer-review. There can be important differences between the submitted version and the official published version of record.

People interested in the research are advised to contact the author for the final version of the publication, or visit the DOI to the publisher's website.

- The final author version and the galley proof are versions of the publication after peer review.

- The final published version features the final layout of the paper including the volume, issue and page numbers.

Link to publication

\footnotetext{
General rights rights.

- You may freely distribute the URL identifying the publication in the public portal. please follow below link for the End User Agreement:

www.umlib.nl/taverne-license

Take down policy

If you believe that this document breaches copyright please contact us at:

repository@maastrichtuniversity.nl

providing details and we will investigate your claim.
}

Copyright and moral rights for the publications made accessible in the public portal are retained by the authors and/or other copyright owners and it is a condition of accessing publications that users recognise and abide by the legal requirements associated with these

- Users may download and print one copy of any publication from the public portal for the purpose of private study or research.

- You may not further distribute the material or use it for any profit-making activity or commercial gain

If the publication is distributed under the terms of Article $25 \mathrm{fa}$ of the Dutch Copyright Act, indicated by the "Taverne" license above, 
Methodiek Schoolverlatersinformatiesysteem 2004 en 2005

ROA-W-2007/2

Timo Huijgen, Paul van der Kolk

Researchcentrum voor Onderwijs en Arbeidsmarkt

Faculteit der Economische Wetenschappen en Bedrijfskunde Universiteit Maastricht

Maastricht, maart 2007 
ISBN: 978-90-5321-454-1

Sec07.026.doc 


\section{Inhoud}

Pagina

1 Algemeen 1

1.1 Inleiding 1

1.2 De VO en BVE Monitor 1

1.3 De HBO Monitor 3

1.4 De WO Monitor 4

2 Vragenlijsten $\quad 5$

2.1 Algemeen 5

2.2 De VO en BVE Monitor 6

2.3 HBO Monitor 6

2.4 WO Monitor $\quad 7$

3 Classificaties $\quad 7$

$\begin{array}{ll}3.1 \text { Opleidingen } & 7\end{array}$

3.2 Beroepen 8

3.3 Branches 8

3.4 Plaatsnamen 8

4 Dataverzameling en respons 8

4.1 VO- en BVE Monitor 9

4.2 HBO Monitor 12

4.3 WO Monitor 13

5 Datacleaning $\quad 14$

6 Nieuwe variabelen 16

7 Weging 18

7.1 VO- en BVE Monitor 18

$\begin{array}{ll}7.2 \text { HBO Monitor } & 20\end{array}$

$\begin{array}{ll}7.3 \text { WO Monitor } & 20\end{array}$

$\begin{array}{ll}7.4 \text { Controle op weegfactoren } & 20\end{array}$ 



\section{Algemeen}

\subsection{Inleiding}

Het Researchcentrum voor Onderwijs en Arbeidsmarkt (ROA) voert jaarlijks vier grootschalige schoolverlatersonderzoeken uit. Doel van deze onderzoeken is het verschaffen van inzicht in de relatie tussen het gevolgde onderwijs en de intrede op de arbeidsmarkt. Daarnaast kan de doorstroom binnen het onderwijs nader worden onderzocht. Bij alle vier de onderzoeken wordt schoolverlaters c.q. afgestudeerden ongeveer anderhalf jaar na het behalen van het diploma geënquêteerd. De vier onderzoeken bestaan uit de VO Monitor (VMBO, HAVO en VWO), de BVE Monitor (BOL en BBL), de HBO Monitor (het hoger beroepsonderwijs) en de WO Monitor (het universitair onderwijs). De monitoren kunnen tenslotte door onderwijsinstellingen gebruikt worden als belangrijk instrument binnen hun kwaliteitszorg. Bij al deze onderzoeken gaat het om de gediplomeerde uitstroom uit het reguliere, door de overheid bekostigde onderwijs.

Het ROA heeft de projectleiding over deze schoolverlatersonderzoeken en is verantwoordelijk voor de instrumentontwikkeling en de wetenschappelijke analyses en rapportages. Dit houdt o.a. in dat het ROA de vragenlijsten samenstelt, de data controleert, opschoont en bewerkt en de landelijke rapportages verzorgt. Het veldwerk wordt verzorgd door DESAN Research Solutions BV, die o.a. de internetscripts maakt, de vragenlijsten en brieven verstuurd, de internetfaciliteiten beschikbaar stelt, de data-invoer, het coderen en de afzonderlijke instellingsrapportages verzorgt.

In dit werkdocument wordt nader ingegaan op de (technische) uitvoering van bovengenoemde onderzoeken. Hierbij wordt allereerst een korte omschrijving van de populatie en steekproef van de verschillende monitoren gegeven (paragrafen 1.2, 1.3 en 1.4). Vervolgens wordt ingegaan op de vragenlijsten (hoofdstuk 2), de gebruikte classificaties (hoofdstuk 3), de dataverzameling en de respons (hoofdstuk 4), de gehanteerde datacleaning (hoofdstuk 5), de berekende nieuwe variabelen en de toegepaste weging (hoofdstukken 6 en 7).

\subsection{De VO en BVE Monitor}

Populatie VO Monitor

Gediplomeerde schoolverlaters van het algemeen voortgezet onderwijs (HAVO en VWO) en het voorbereidend middelbaar beroepsonderwijs (VMBO, inclusief de theoretische leerweg (voorheen bekend als MAVO)).

\section{Steekproef VO Monitor}

De namen en adressen van de te benaderen schoolverlaters worden aangeleverd door de deelnemende onderwijsinstellingen. De steekproef is afhankelijk van het aantal deelnemende instellingen. Door de aard van het onderwijs, de constante deelname in de afgelopen 
jaren en de geringe regionale verschillen tussen identieke opleidingen binnen deze onderwijsniveaus zijn de verkregen data landelijk representatief.

Populatie BVE BOL

In het kader van de BVE Monitor worden zowel gediplomeerde als ongediplomeerde schoolverlaters van de beroepsopleidende leerweg (BOL) benaderd.

\section{Steekproef BVE BOL}

De BOL steekproef bestaat uit twee bronnen. Allereerst wordt onderwijsinstellingen gevraagd deel te nemen aan de reguliere BVE Monitor. Deze instellingen leveren vervolgens de adressen van de personen die gediplomeerd de instelling verlaten hebben. Ten tweede wordt via de IB Groep in Groningen een landelijke, naar opleiding en regio, representatieve steekproef getrokken op basis van hun leerlingenbestanden. Hierbij worden niet alleen gediplomeerde maar ook ongediplomeerde leerlingen benaderd. Er wordt bij deze IB steekproef rekening gehouden met de reeds deelnemende onderwijsinstellingen, zodat er geen adressen of onderwijsinstellingen dubbel worden benaderd.

\section{Populatie BVE BBL}

In het kader van de BVE Monitor worden gediplomeerde schoolverlaters van de beroepsbegeleidende leerweg (BBL) benaderd. Leerlingen die het diploma van een bepaald $B B L$ niveau behaald hebben en binnen de instelling verder studeren in een studie met een hoger niveau worden niet benaderd.

\section{Steekproef BVE BBL}

Net als de BOL steekproef wordt onderwijsinstellingen gevraagd deel te nemen aan de reguliere BVE Monitor. De steekproefadressen voor de BBL worden geleverd door de deelnemende onderwijsinstellingen. Voor BBL was tot en met 2006 nog geen landelijke steekproef via IBG mogelijk waardoor voor dit opleidingstype de landelijke data niet landelijk representatief zijn. Met ingang van 2007 zal dit wel het geval zijn.

In tabel 1.1 staan de aantallen benaderde schoolverlaters en de totale populatie van de afgelopen twee meetjaren verdeeld naar onderwijssoort. Het meetjaar 2004 heeft betrekking op scholieren die in het studiejaar 2002/2003 hun diploma behaald hebben. Meetjaar 2005 heeft de gediplomeerden van schooljaar 2003/2004 als populatie. 
Tabel 1.1

Populatie en benaderd aantal schoolverlaters VO en BVE

\begin{tabular}{|c|c|c|c|c|}
\hline \multirow[t]{2}{*}{ Onderwijssoort } & \multicolumn{2}{|c|}{ Meetjaar 2004} & \multicolumn{2}{|c|}{ Meetjaar 2005} \\
\hline & Benaderd & Populatie & Benaderd & Populatie \\
\hline AVO & 6.286 & 60.244 & 6.076 & 63.976 \\
\hline HAVO & 3.417 & 34.255 & 3.256 & 36.578 \\
\hline VWO & 2.869 & 25.989 & 2.820 & 27.398 \\
\hline VMBO & 6.478 & 79.146 & 6.199 & 84.672 \\
\hline Theoretische leerweg & 2.077 & 38.147 & 2.566 & 39.628 \\
\hline Landbouw & 2.435 & 6.103 & 2.323 & 6.022 \\
\hline Techniek & 823 & 14.373 & 557 & 17.228 \\
\hline Economie & 645 & 10.740 & 466 & 11.494 \\
\hline Gezondheidszorg & 498 & 9.783 & 287 & 10.300 \\
\hline$B O L^{1}$ & 26.969 & 62.869 & 27.337 & 74.813 \\
\hline$B B L^{2}$ & 6.447 & 40.007 & 4.140 & -- \\
\hline Landbouw & 1.832 & 3.095 & 1.238 & -- \\
\hline Techniek & 1.348 & 11.744 & 1.204 & -- \\
\hline Economie & 1.583 & 9.557 & 864 & -- \\
\hline Gezondheidszorg & 1.433 & 12.771 & 711 & -- \\
\hline Gedrag en Maatschappij & 251 & 2.840 & 123 & -- \\
\hline
\end{tabular}

\subsection{De HBO Monitor}

In samenwerking met de HBO raad voert het ROA al sinds 1990 een arbeidsmarktmonitor uit onder de afgestudeerden van het hoger beroepsonderwijs.

\section{Steekproef HBO Monitor}

De benodigde adresgegevens van de gediplomeerden zijn afkomstig uit de bestanden van de hogescholen. De deelname van de hogescholen aan de HBO Monitor gebeurt op basis van vrijwilligheid en is al vele jaren zeer hoog. De afgelopen jaren lag het percentage benaderde afgestudeerden rond de 75 procent. Voor de studiejaren geldt dat de afstudeerdatum tussen 1 september en 31 augustus dient te liggen.

\section{Populatie HBO Monitor}

De populatie van de HBO Monitor bestaat uit de afgestudeerden van alléén de HBO bachelor opleidingen (en de nog resterende uitstroom van de vergelijkbare oude opleidingsvarianten). In het gehele hoger onderwijs is sinds 2002 de 'bachelor-master' structuur ingevoerd. In het HBO zijn hierbij de bachelor opleidingen de equivalenten van de

1. Bij de landelijke BOL steekproef door de IB groep is het niveau en de richting van de gevolgde opleiding niet bekend. De cijfers voor BOL kunnen daarom niet per sector worden weergegeven.

2. In meetjaar 2005 was het niet mogelijk de BBL te wegen naar landelijke populatiecijfers. 
reguliere HBO opleidingen uit de oude structuur. De master opleidingen kunnen vergeleken worden met de vroegere $\mathrm{HBO} 2^{\mathrm{e}}$ fase opleidingen (post initieel onderwijs).

In tabel 1.2 staan de aantallen benaderde personen en de totale populatie van de afgelopen twee meetjaren. Het meetjaar 2004 heeft betrekking op afgestudeerden van het studiejaar 2002/2003, meetjaar 2005 op afgestudeerden van het studiejaar 2003/2004. In de beide meetjaren bestaat de steekproef nog voor een deel uit uitstroom van de oude structuur opleidingen en voor een deel uit uitstroom uit nieuwe, bachelor opleidingen. In de komende jaren zal de uitstroom uit de eerstgenoemde groep langzaam verdwijnen.

Tabel 1.2

Populatie en benaderd aantal afgestudeerden HBO

\begin{tabular}{|c|c|c|c|c|}
\hline \multirow[t]{2}{*}{ Onderwijssoort } & \multicolumn{2}{|c|}{ Meetjaar 2004} & \multicolumn{2}{|c|}{ Meetjaar 2005} \\
\hline & Benaderd & Populatie & Benaderd & Populatie \\
\hline HBO & 47.917 & 62.752 & 47.537 & 62.618 \\
\hline Landbouw & 1.623 & 2.913 & 1.772 & 1.963 \\
\hline Onderwijs & 7.176 & 12.556 & 8.087 & 11.332 \\
\hline Techniek & 8.549 & 10.810 & 7.354 & 10.889 \\
\hline Economie & 15.290 & 18.372 & 15.391 & 19.777 \\
\hline Gezondheidszorg & 5.406 & 7.004 & 4.955 & 6.698 \\
\hline Gedrag en Maatschappij & 7.214 & 8.954 & 6.962 & 9.055 \\
\hline Taal en cultuur & 2.659 & -- & 3.016 & -- \\
\hline
\end{tabular}

\subsection{De WO Monitor}

\section{Populatie WO Monitor}

De populatie van de WO Monitor bestaat uit twee groepen.

Allereerst behoren de afgestudeerden van de master opleidingen tot de populatie. Deze masters zijn te vergelijken met de uitstroom uit de vroegere initiële WO opleidingen. Ten tweede behoort de uitstroom uit de bachelor opleidingen tot de populatie voor zover die niet zijn doorgestroomd naar een master opleiding. De afstudeerdatum dient bij de WO Monitor tussen 1 oktober en 30 september te liggen.

\section{Steekproef WO Monitor}

De WO Monitor vindt in VSNU verband plaats onder de afgestudeerden van alle 13 Nederlandse universiteiten. Hierbij neemt het ROA voor 10 universiteiten de uitvoering voor haar rekening. De Radboud Universiteit Nijmegen, de Universiteit Twente en de Rijksuniversiteit Groningen dragen zelf zorg voor de uitvoering. De benodigde adresgegevens zijn afkomstig uit de bestanden van de universiteiten. Evenals in het hoger beroepsonderwijs is men in het universitair onderwijs overgegaan tot de invoering van de bachelor-master opleidingstructuur. Bachelors waarvan bekend is dat ze zijn doorgestroomd naar een master opleiding worden niet in de steekproef opgenomen. Deze master opleiding kan daarbij aan de eigen universiteit of aan een andere universiteit gevolgd worden. Reden hiervoor is dat 
de verder studerende bachelors toch al benaderd worden indien ze afstuderen aan een master opleiding. Daarnaast hebben ze vaak op het moment van enquêteren, ongeveer anderhalf jaar na hun afstuderen, ook de master (vervolg)opleiding met succes afgerond.

De populatiecijfers van het WO staan in tabel 1.3. Het meetjaar 2004 heeft betrekking op afgestudeerden van het academisch jaar 2002/2003, meetjaar 2005 op afgestudeerden van het academisch jaar 2003/2004.

Tabel 1.3

Populatie en benaderd aantal afgestudeerden WO

Onderwijssoort

Meetjaar 2004

Meetjaar $2005^{3}$

Benaderd/populatie

Benaderd/populatie

\begin{tabular}{lrr} 
WO & 22.231 & 24.164 \\
Landbouw & 607 & 646 \\
Techniek & 2.725 & 2.875 \\
Economie & 3.954 & 4.865 \\
Gezondheidszorg & 3.008 & 2.986 \\
Gedrag en Maatschappij & 4.628 & 5.035 \\
Taal en cultuur & 2.570 & 2.813 \\
Recht en Openbare Orde & 3.044 & 3.366 \\
Natuurwetenschappen & 1.695 & 1.578 \\
\hline
\end{tabular}

\section{Vragenlijsten}

\subsection{Algemeen}

De ROA schoolverlatersonderzoeken worden sinds het uitvoeringsjaar 1996 volgens een geïntegreerd model uitgevoerd. Hierbij is sprake van één meetmoment en wordt er zoveel mogelijk gestreefd naar één set kernvragen. Ondanks deze set kernvragen bestaan er meerdere vragenlijsten. Hiermee wordt recht gedaan aan de verschillen tussen de diverse onderwijsniveaus en -sectoren. Zo heeft ieder onderwijsniveau zijn eigen vragenlijst en zijn er aparte varianten voor het agrarisch onderwijs. In het HBO is er tevens een aparte lijst voor de kunstensector. In onderstaand hoofdstuk wordt ingegaan op de veranderingen die op de vragenlijsten in de meetjaren 2004 en 2005 zijn doorgevoerd. Een deel van de veranderingen zijn incidenteel van aard en worden verder niet besproken. Hier wordt alleen gekeken naar veranderingen die meer structureel van aard zijn en behoren tot de set van basisvragen.

3. In dit meetjaar zijn bij 1 universiteit abusievelijk alle bachelor afgestudeerden benaderd, dus ook degenen die een master vervolgstudie zijn gaan doen. 


\subsection{De VO en BVE Monitor}

De VO monitor bestaat uit een VMBO vragenlijst en een HAVO/VWO vragenlijst. Voor beide vragenlijsten geldt dat er in 2004 en 2005 niet veel wijzigingen hebben plaatsgevonden. In het VMBO is er in 2004 definitief overgegaan met het invoeren van de afkorting VMBO op de vragenlijst in plaats van de in 2003 nog gebruikte term VBO/MAVO. Dit heeft tot gevolg gehad dat er niet meer gevraagd is naar het examenniveau maar naar de gevolgde leerweg. Tot en met 2003 werd het niveau van de gevolgde opleiding indirect afgeleid uit de niveaus van de gevolgde vakken. Vanaf 2004 is dit niveau direct af te leiden uit de vraag over de gevolgde leerweg. Met het oog op het ook geografisch in kaart brengen van de doorstroom naar het vervolgonderwijs is vanaf meetjaar 2005 een vraag opgenomen over de naam en de plaats van de instelling waar de vervolgopleiding genoten wordt.

In de HAVO/VWO vragenlijst is de aspectenvraag met betrekking tot de aansluiting met het vervolgonderwijs in 2005 gewijzigd. De items op de aspectenlijst zijn hetzelfde gebleven maar de onderdelen waarop ze beoordeeld moeten worden zijn veranderd. Zo zijn de onderdelen 'in hoeverre ieder aspect nodig is in de vervolgopleiding' en 'waar het aspect vooral geleerd is' komen te vervallen. Hier voor in de plaats is gevraagd naar het in de vervolgopleiding vereiste niveau (5-punt schaal). De antwoordcategorieën van het onderdeel over de mate van beheersing is veranderd van een 3-punt schaal naar een 5-punt schaal.

In 2005 zijn twee vragen komen te vervallen op de BOL - en de BBL vragenlijst. Het gaat om de vraag over de redenen voor het volgen van een vervolgopleiding en om de vraag over de bij de huidige functie horende leeractiviteiten. Evenals op de VMBO vragenlijst wordt, sinds 2005, op beide lijsten naar de naam en plaats van de instelling waar men eventueel een vervolgopleiding volgt gevraagd.

\subsection{HBO Monitor}

In meetjaar 2004 is in de HBO vragenlijst een onderdeel van de competentievraag komen te vervallen. Het betreft de vraag waar respondenten aangeven waar ze een bepaalde competentie vooral geleerd hebben. Daarnaast is de vraag over de tijdens de studie opgedane buitenlandervaring uitgebreid.

In 2005 is een vraag weggevallen die betrekking had op de gebruikte werkvormen (hoorcolleges, practica e.d) tijdens de opleiding. Daarnaast is niet meer gevraagd hoeveel maanden men sinds het verlaten van de opleiding werkloos geweest is. Een vraag die tot en met meetjaar 2002 gesteld werd maar in de jaren daarna achterwege is gelaten is op verzoek van onderwijsinstellingen weer toegevoegd. Het betreft de vraag waarin aan respondenten gevraagd wordt verschillende onderdelen/aspecten van de gevolgde opleiding te beoordelen met een rapportcijfer. Hierbij gaat het niet alleen om het studieprogramma maar ook om zaken als de beschikbare voorzieningen en de kwaliteit van de studiebegeleiding. 


\subsection{WO Monitor}

De (kern-)vragenlijst die gebruikt wordt in de WO Monitor wordt in VSNU verband door alle 13 universiteiten gezamenlijk opgesteld en jaarlijks aangepast. De kernvragen van de HBO Monitor en de WO Monitor zijn al sinds een aantal jaren vrijwel identiek. Dit omdat de benodigde kernindicatoren, voor zowel landelijke statistieken als onderwijsinstellingen zelf, in het hoger onderwijs voor een groot deel gelijk zijn. Dit komt mede door de in 2002 ingevoerde bachelor-master structuur binnen het gehele hogere onderwijs. De verschillen tussen de HBO vragenlijst en de WO vragenlijst zijn gering voor zover het de kernvragen betreft. Dit in verband met de vergelijkbaarheid binnen het gehele hoger onderwijs. De in de uitvoeringsjaren 2004 en 2005 doorgevoerde wijzigingen in de kern van de HBO lijst (zie vorige paragraaf) zijn dan ook van toepassing op de WO vragenlijsten.

\section{Classificaties}

Voor een aantal open vragen in de enquête worden de antwoorden volgens een standaardclassificatie gecodeerd. Het gaat hierbij om kenmerken als opleiding, beroep, bedrijven c.q. branches en plaatsnamen.

\subsection{Opleidingen}

Voor het coderen van opleidingen wordt gebruik gemaakt van een door het ROA ontwikkelde opleidingsclassificatie. Omdat de bestaande nationale en internationale classificaties niet voldoen aan de eisen met betrekking tot mate van specificiteit en praktische bruikbaarheid is er voor gekozen een eigen indeling te hanteren. Deze classificatie is koppelbaar aan de nationaal veel gehanteerde Standaard Onderwijs Indeling (SOI) van het CBS, het Centraal Register Beroepsopleidingen (CREBO), het Centraal Register Opleidingen Hoger Onderwijs $(\mathrm{CROHO})$, en de onderwijsclassificatie International Standard Classification of Education (ISCED).

In de ROA classificatie wordt onderscheid gemaakt naar onderwijstype, onderwijsvorm (regulier/duaal), fase (korte (middel-) lange opleidingen), sector, opleiding en eventueel de richting binnen de opleiding. De classificatie wordt jaarlijks bijgewerkt en wordt gebaseerd op studiegidsen, bestaande administratieve opleidingsindelingen zoals CREBO en CROHO en informatie van de deelnemende onderwijsinstellingen zelf.

Zoals eerder vermeld is in 2002 de Bachelor-Master structuur ingevoerd in het hoger onderwijs. Het onderscheid tussen opleidingen uit de oude structuur en de nieuwe BaMA opleidingen is voor onderzoeksdoeleinden van groot belang. Daarom zijn er in de opleidingsclassificatie voor de BaMa opleidingen ook nieuwe opleidingscodes gecreëerd. In het HBO zijn dit met name bachelor varianten aangezien deze vergelijkbaar zijn met de reguliere, oude $\mathrm{HBO}$ opleidingen en afgestudeerden van de $\mathrm{HBO}$ master opleidingen niet tot de populatie behoren. De master HBO opleidingen zijn dus vooralsnog in beperkte mate in 
de classificatie ondergebracht. Voor het WO zijn zowel de bachelor als de master varianten in de classificatie opgenomen.

\subsection{Beroepen}

De beroepen worden gecodeerd aan de hand van de Standaard Beroepenclassificatie van het CBS (SBC-92). De SBC-92 is een classificatie van beroepen op grond van niveau en richting van de benodigde bekwaamheden om het beroep uit te oefenen in combinatie met de (maximaal 3) belangrijkste werksoorten. Er worden 1211 beroepen onderscheiden, ingedeeld in 43 beroepsklassen 121 beroepsgroepen. De SBC is koppelbaar aan de internationaal veel gehanteerde ISCO indeling.

Omdat sommige beroepen binnen de SBC niet specifiek genoeg zijn is er door het ROA in incidentele gevallen een nog verdere onderverdeling gemaakt. Hierdoor zijn in de ROA schoolverlatersbestanden de beroepencodes 6 cijferig en niet 5 cijferig zoals in de CBS classificatie. In de ROA beroepencode-variant is als $6^{\mathrm{e}}$ digit aan alle SBC codes een nul toegevoegd zodat er, daar waar nodig, toch ruimte is voor een nadere specificatie. Zo is bijvoorbeeld de SBC code 93208 'Advocaat, notaris, rechter, officier van justitie, juridisch adviseur' in de schoolverlatersdata niet alleen uitgebreid naar de 6 digit code 932080 maar ook nader gedifferentieerd naar 932081 'Advocaat', 932082 'Officier van justitie' enz.

\subsection{Branches}

Voor het coderen van bedrijven en branches is gebruik gemaakt van de Standaard Bedrijfsindeling (SBI-1993) van het CBS. De SBI is een systematische hiërarchische indeling van economische activiteiten die zes niveaus kent. Evenals bij de SBC is de SBI voor de schoolverlatersonderzoeken uitgebreid van een 5 cijferige code naar een 6 digit code. De SBI sluit aan bij de door Eurostat vastgestelde NACE indeling.

\subsection{Plaatsnamen}

Plaatsnamen worden gecodeerd aan de hand van gemeentecodes uit de meest recente versie van het Plaatsnamenregister welke afkomstig is van CENDRIS (een onderdeel van TNT Post).

\section{Dataverzameling en respons}

De wijze van dataverzameling gebeurde in 2004 en 2005 veelal schriftelijk of via Internet. Onderstaand een schematisch overzicht van het veldwerk per onderwijssoort voor uitvoeringsjaar 2004 en 2005. 


\subsection{VO- en BVE Monitor}

\section{AVO en $V M B O$}

De adressen voor het benaderen van schoolverlaters van het AVO en het VMBO zijn afkomstig van de deelnemende onderwijsinstellingen. De verzending van de aanbiedingsbrieven gebeurd door DESAN of door de onderwijsinstelling zelf. Bij centrale verzending leveren de scholen het adressenbestand aan DESAN. Zowel in 2004 als in 2005 is voor het AVO zo'n $15 \%$ van de vragenlijsten door de onderwijsinstellingen zelf verstuurd. In het VMBO was dit in 2004 23\% en in 2005 15\%.

Overzicht 4.1

Wijze van dataverzameling

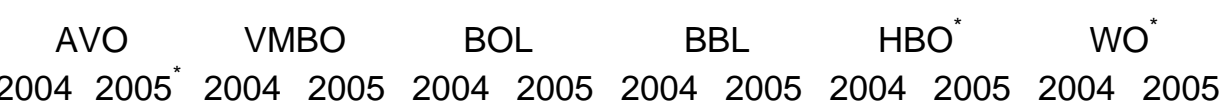

\section{Verzending via:}

Deelnemende onderwijsinstelling

DESAN

$15 \% \quad 15 \%$

$23 \% \quad 15 \%$

$8 \% \quad 1 \%$

$62 \% \quad 39 \%$

$4 \%$

96\% $100 \%$

$4 \% \quad 1 \%$

$20 \%$

$20 \%$

IB Groep

$30 \% \quad 60 \%$

Eerste mailing

Vragenlijst

bijgevoegd?

Eerste rappel

Vragenlijst

$85 \% \quad 85 \% \quad 77 \% \quad 85 \%$$$
96 \% \quad 99 \% \quad 80 \% \quad 80 \%
$$

bijgevoegd?

Tweede rappel

Vragenlijst

bijgevoegd?

Derde rappel

$$
\begin{aligned}
& \text { post post post post post post post } \\
& \text { ja post nee nee nee nee nee nee e-mail e-mail e-mail e-mail } \\
& \text { post post post post post post post } \\
& \text { nee post ja ja ja ja ja ja e-mail e-mail e-mail e-mail } \\
& \text { post post post post post post } \\
& \text { nee nee nee nee nee nee post post post post } \\
& \text { post post post post }
\end{aligned}
$$

* = dataverzameling alleen en volledig via internet

In beide meetjaren zijn in het VMBO alle aanbiedingsbrieven met de reguliere post verstuurd en niet via email. Aangezien de mogelijkheid bestond om via internet de enquête in te vullen was bij de eerste mailing nog geen vragenlijst toegevoegd. Deze is met de eerste rappel verstuurd. Voor scholen waar ook na de eerste rappel nog sprake was van een lage respons is nog een tweede rappelzending verstuurd. Voor het AVO was er wel een verschil in aanpak voor beide meetjaren. In 2004 zijn voor het AVO alle brieven per post verstuurd en is een vragenlijst bij de eerste rappel toegevoegd. Voor zowel meetjaar 2004 als 2005 gold ook voor het AVO dat alleen een tweede rappel verstuurd is voor die scholen waar de respons achter bleef. Vanwege de lagere kosten en de traditioneel hoge respons onder AVO scholieren is echter in 2005 de mogelijkheid voor het schriftelijk invullen van de vragenlijst voor het AVO vervallen. 
Tabel 4.1

Respons en wijze van enquêteren VO- en BVE Monitor ${ }^{4}$

\begin{tabular}{|c|c|c|c|c|c|c|c|c|}
\hline \multirow[b]{2}{*}{$\begin{array}{l}\text { Onderwijs- } \\
\text { soort }\end{array}$} & \multicolumn{5}{|c|}{$\begin{array}{l}2004 \\
\text { Enquêtemethode }\end{array}$} & \multicolumn{3}{|c|}{$\begin{array}{l}2005 \\
\text { Enquêtemethode }\end{array}$} \\
\hline & $\begin{array}{c}\text { Respons } \\
\%\end{array}$ & $\begin{array}{c}\text { Internet } \\
\%\end{array}$ & $\begin{array}{c}\text { Schrifte- } \\
\text { lijk } \\
\%\end{array}$ & $\begin{array}{c}\text { Tele- } \\
\text { fonisch } \\
\%\end{array}$ & $\begin{array}{c}\text { Respons } \\
\%\end{array}$ & $\begin{array}{c}\text { Internet } \\
\%\end{array}$ & $\begin{array}{c}\text { Schrifte- } \\
\text { lijk } \\
\%\end{array}$ & $\begin{array}{c}\text { Tele- } \\
\text { fonisch } \\
\%\end{array}$ \\
\hline AVO & 64 & 76 & 24 & & 45 & 100 & & \\
\hline HAVO & 62 & 77 & 23 & & 41 & 100 & & \\
\hline VWO & 66 & 76 & 24 & & 49 & 100 & & \\
\hline VMBO & 45 & 40 & 60 & & 43 & 58 & 42 & \\
\hline VMBO TL & 48 & 44 & 56 & & 42 & 62 & 38 & \\
\hline Landbouw & 44 & 46 & 54 & & 44 & 57 & 43 & \\
\hline Techniek & 42 & 24 & 76 & & 38 & 48 & 52 & \\
\hline Economie & 38 & 29 & 71 & & 39 & 54 & 46 & \\
\hline Gezondheidszorg & 49 & 29 & 71 & & 57 & 56 & 44 & \\
\hline BOL niveau $1 / 2$ & 31 & 73 & 27 & & 30 & 65 & 27 & 8 \\
\hline Landbouw & 42 & 40 & 60 & & 37 & 77 & 23 & \\
\hline Techniek & 29 & 84 & 16 & & 24 & 63 & 24 & 13 \\
\hline Economie & 28 & 72 & 28 & & 28 & 64 & 29 & 7 \\
\hline Gezondheidszorg & 35 & 74 & 26 & & 38 & 68 & 28 & 4 \\
\hline BOL niveau 3/4 & 45 & 76 & 24 & & 39 & 81 & 19 & \\
\hline Landbouw & 47 & 50 & 50 & & 41 & 79 & 21 & \\
\hline Techniek & 39 & 83 & 17 & & 37 & 84 & 16 & \\
\hline Economie & 42 & 80 & 20 & & 37 & 81 & 18 & 1 \\
\hline Gezondheidszorg & 48 & 76 & 24 & & 40 & 78 & 22 & \\
\hline $\begin{array}{l}\text { Gedrag en } \\
\text { maatsch. }\end{array}$ & 53 & 77 & 23 & & 37 & 79 & 21 & \\
\hline BBL niveau $1 / 2$ & 29 & 37 & 61 & 2 & 25 & 59 & 33 & 8 \\
\hline Landbouw & 31 & 34 & 66 & & 27 & 65 & 35 & \\
\hline Techniek & 30 & 42 & 50 & 8 & 25 & 51 & 33 & 16 \\
\hline Economie & 23 & 46 & 52 & 2 & 25 & 68 & 21 & 11 \\
\hline Gezondheidszorg & 30 & 27 & 73 & & 19 & 40 & 51 & 9 \\
\hline BBL niveau 3/4 & 34 & 48 & 52 & & 29 & 72 & 28 & \\
\hline Landbouw & 37 & 46 & 54 & & 33 & 75 & 25 & \\
\hline Techniek & 27 & 55 & 45 & & 30 & 69 & 31 & \\
\hline Economie & 30 & 58 & 42 & & 26 & 74 & 26 & \\
\hline $\begin{array}{l}\text { Gezondheidszorg } \\
\text { Gedrag en }\end{array}$ & 35 & 38 & 62 & & 29 & 66 & 34 & \\
\hline maatsch. & 41 & 50 & 50 & & 15 & 84 & 16 & \\
\hline
\end{tabular}

In tabel 4.1 staan per onderwijssector de wijze van enquêteren en de responscijfers vermeld. In vergelijking met andere onderwijssoorten is voor het AVO de respons redelijk hoog alhoewel er wel een duidelijke daling is opgetreden in 2005 ten opzichte van 2004. Dit heeft wellicht te maken met het wegvallen van de mogelijkheid om de vragenlijst schriftelijk in te

4. Bij de landelijke BOL steekproef door de IB groep is het niveau en de richting van de gevolgde opleiding niet bekend, daardoor zijn de responscijfers voor BOL exclusief de IB Groep steekproef. 
vullen. Uit de cijfers van 2004 blijkt dat slechts een kwart van de AVO respondenten er voor gekozen had de vragenlijst schriftelijk in te vullen. Onder de VMBO schoolverlaters ligt dit percentage aanzienlijk lager. Alhoewel er tussen de VMBO sectoren grote verschillen zijn vulde in 2004 nog 60\% de vragenlijst schriftelijk in. In 2005 was dit percentage gezakt naar $42 \%$. Ondanks dat dus ook steeds meer VMBO schoolverlaters kiezen voor de internet enquête ligt het percentage schriftelijke lijsten nog te hoog om ook hier over te gaan tot enkel nog een internet versie. Het responspercentage onder de gediplomeerde VMBO-ers is ten opzichte van BOL en BBL redelijk hoog en was in 2005 2\% lager dan in 2004.

\section{$B O L$ en $B B L$}

De adressen voor het aanschrijven van de BBL uitstroom zijn afkomstig van de deelnemende onderwijsinstellingen. Ook hier hebben de instellingen de keuze om zelf de vragenlijsten te versturen zodat ze geen adressen aan DESAN hoeven aan te leveren. In 2004 gebeurde dit slechts voor 4\% van de vragenlijsten en in 2005 heeft DESAN zelfs alle mailings voor het BBL verzorgd. De opzet van het onderzoek onder de gediplomeerde BOL uitstroom is, zoals reeds eerder gemeld, te splitsen in twee deelonderzoeken voor zover het de adresgegevens betreft. Allereerst kunnen scholen zich aanmelden voor deelname en leveren zij dus ook de gegevens voor het verzenden van de vragenlijsten. In 2004 is $8 \%$ van de vragenlijsten door de scholen zelf verzonden, in 2005 is voor het BOL de gehele verzending door DESAN verzorgd. Om tot een landelijk voor regio en sector dekkende BOL steekproef te komen worden er, aanvullend op de deelname van de scholen, door de IB Groep ook nog jaarlijks zo'n 16.000 BOL afgestudeerden benaderd. Vanwege privacywetgeving omtrent de adressenbestanden die in het beheer van de IB Groep zijn wordt de verzending van deze aanvullende steekproef door de IB Groep zelf verzorgd.

Bij de reguliere, niet IB aangeschrevenen, zijn er voor zowel BOL als BBL in 2004 en in 2005 twee mailingen per post gedaan. Hierbij is de vragenlijst pas bij de tweede mailing (eerste rappel) meegestuurd. In 2004 was er bij de IB steekproef eveneens sprake van twee verzendingen waarbij de vragenlijst bij de eerste rappel was toegevoegd. In 2005 is er voor de laatstgenoemde steekproef ook nog een tweede rappel de deur uit gegaan.

Binnen de schoolverlatersonderzoeken is de respons onder de BBL gediplomeerden altijd laag geweest. Ook in de jaren 2004 en 2005 was dit het geval (zie tabel 4.1). BOL respondenten scoren wat betreft respons iets hoger dan de BBL respondenten. Ten opzichte van 2004, en zeker ten opzichte van eerdere meetjaren is de respons van zowel BOL als BBL gedaald in 2005. Een verklaring hiervoor kan de centrale verzending van de vragenlijsten zijn. Onderwijsinstellingen die decentraal, dus zelf de verzending verzorgen bleken in het verleden vaak over betere adressenbestanden te beschikken dan de onderwijsinstellingen die dat niet deden. Een tweede voordeel van decentrale verzending is het gebruik van eigen briefpapier en eigen logo's hetgeen, in vergelijking met neutraal briefpapier, responsverhogend werkt. Bij het centraal verzenden van de enquête wordt in de regel neutraal briefpapier gebruikt. In het afgelopen meetjaar waren er echter geen scholen die zelf de verzending verzorgd hebben hetgeen het responspercentage gedrukt heeft. 
Uit tabel 4.1 blijkt verder dat er bij zowel BOL als BBL een verschuiving in de wijze van enquêteren aan het plaatsvinden is. Steeds meer respondenten kiezen voor de internet variant van de vragenlijst in plaats van de schriftelijke lijst. Van de BOL niveau 3/4 respondenten koos in 2005 zelfs $81 \%$ voor de internetvragenlijst. Wellicht kan ook voor deze onderwijsniveaus over enkele jaren alleen het aanbieden van een internetvragenlijst voldoende zijn. De telefonische respons in tabel 4.1 heeft betrekking op de regio Rotterdam. De gemeente Rotterdam heeft met een grote steekproef meegedaan met de monitor. Hierbij is er voor gekozen om, vanwege de lage te verwachten respons, de laagst opgeleiden (niveaus 1 en 2) met een telefonische enquête te benaderen.

\subsection{HBO Monitor}

In tabel 4.2 staan enkele cijfers over de respons en de wijze van enquêteren met betrekking tot de HBO Monitor van de afgelopen twee jaren. In het verleden is gebleken dat een hoog percentage van de respondenten de vragenlijst bij voorkeur via internet invult. Dit in combinatie met de hoge respons onder afgestudeerden van het hoger onderwijs heeft er toe geleid dat de HBO- en de WO Monitor in 2004 en 2005 alleen nog via internet zijn uitgevoerd.

Tabel 4.2

Respons en wijze van enquêteren HBO Monitor

\begin{tabular}{|c|c|c|c|c|c|c|}
\hline \multirow{3}{*}{$\begin{array}{l}\text { Onderwijs- } \\
\text { soort }\end{array}$} & \multicolumn{3}{|c|}{$\begin{array}{l}2004 \\
\text { Enquêtemethode }\end{array}$} & \multicolumn{3}{|c|}{$\begin{array}{l}2005 \\
\text { Enquêtemethode }\end{array}$} \\
\hline & Respons & Internet & $\begin{array}{c}\text { Tele- } \\
\text { fonisch }\end{array}$ & Respons & Internet & $\begin{array}{l}\text { Tele- } \\
\text { fonisch }\end{array}$ \\
\hline & $\%$ & $\%$ & $\%$ & $\%$ & $\%$ & $\%$ \\
\hline $\mathrm{HBO}$ & 44 & 98 & 2 & 45 & 98 & 2 \\
\hline Landbouw & 48 & 100 & & 51 & 100 & \\
\hline Onderwijs & 43 & 98 & 2 & 45 & 98 & 2 \\
\hline Techniek & 47 & 99 & 1 & 47 & 99 & 1 \\
\hline Economie & 43 & 98 & 2 & 42 & 98 & 2 \\
\hline Gezondheidszorg & 48 & 96 & 4 & 50 & 97 & 3 \\
\hline Gedrag en maatsch. & 46 & 97 & 3 & 45 & 98 & 2 \\
\hline Taal en cultuur & 37 & 97 & 3 & 40 & 100 & \\
\hline
\end{tabular}

Alle adressen (post en indien bekend email gegevens) die nodig zijn voor het benaderen van HBO afgestudeerden zijn afkomstig van de deelnemende hogescholen. Voor slechts een kleine groep afgestudeerden worden de vragenlijsten door de hogescholen zelf verstuurd. In 2004 gold dit voor 4\%, in 2005 voor nog maar 1\% van de respondenten. De verzendingen worden dus vrijwel in zijn geheel centraal door DESAN geregeld. Omdat de eerste mailing per email gaat worden de hogescholen verzocht om behalve de postadressen ook zoveel mogelijk email-adressen aan te leveren. In meetjaar 2004 zijn na deze eerste elektronische verzending nog twee schriftelijke rappels verstuurd. In 2005 is er na de eerste email verzending eerst nog een email rappel verstuurd alvorens de twee schriftelijke mailings de deur uit gegaan zijn. Omdat de vragenlijst enkel nog via internet in te vullen is zijn er in beide jaren geen schriftelijke versies van de vragenlijsten verstuurd. Aangezien er bij de intake een 
responsgarantie gegeven wordt aan de hogescholen wordt er door DESAN in sommige gevallen nog een telefonische belronde gehouden. Hierbij wordt in eerste instantie gevraagd om de internet-vragenlijst alsnog in te vullen. Daarna gaat men pas over tot het afnemen van een telefonische enquête. Zoals uit tabel 4.2 blijkt gaat het hierbij om slechts een klein deel van de respondenten. Het responscijfer onder de HBO afgestudeerden lag de afgelopen jaren zo rond de $45 \%$ hetgeen in vergelijking met de andere onderwijsniveaus goed te noemen is. Evenals bij eerdere meetjaren kent de HBO sector Landbouw het hoogste responspercentage en de sector Taal en Cultuur het laagste.

\subsection{WO Monitor ${ }^{5}$}

De WO Monitor heeft evenals de HBO Monitor de afgelopen jaren alleen via een internetenquête plaatsgevonden (zie tabel 4.3).

Tabel 4.3

Respons en wijze van enquêteren WO Monitor

\begin{tabular}{|c|c|c|c|c|c|c|}
\hline \multirow[b]{2}{*}{ OnderwijsSoort } & \multirow[b]{2}{*}{$\begin{array}{c}\text { Respons } \\
\% \\
\end{array}$} & \multicolumn{2}{|c|}{$\begin{array}{l}2004 \\
\text { Enquêtemethode }\end{array}$} & \multirow[b]{2}{*}{$\begin{array}{c}\text { Respons } \\
\% \\
\end{array}$} & \multicolumn{2}{|c|}{$\begin{array}{l}2005 \\
\text { Enquêtemethode }\end{array}$} \\
\hline & & $\begin{array}{c}\text { Internet } \\
\% \\
\end{array}$ & $\begin{array}{c}\text { Telefonisch } \\
\% \\
\end{array}$ & & $\begin{array}{c}\text { Internet } \\
\% \\
\end{array}$ & $\begin{array}{c}\text { Telefonisch } \\
\% \\
\end{array}$ \\
\hline WO & 45 & 98 & 2 & 47 & 99 & 1 \\
\hline Landbouw & 58 & 100 & & 57 & 100 & \\
\hline Onderwijs & 45 & 88 & 12 & 41 & 100 & \\
\hline Techniek & 53 & 100 & & 56 & 100 & \\
\hline Economie & 43 & 98 & 2 & 43 & 99 & 1 \\
\hline Gezondheidszorg & 44 & 98 & 2 & 48 & 99 & 1 \\
\hline Gedrag en maatsch. & 46 & 98 & 2 & 48 & 99 & 1 \\
\hline Taal en cultuur & 43 & 99 & 1 & 46 & 99 & 1 \\
\hline Recht en opb. Orde & 39 & 98 & 2 & 41 & 98 & 2 \\
\hline Natuurwetenschappen & 47 & 99 & 1 & 47 & 100 & \\
\hline
\end{tabular}

De emailgegevens en de postadressen zijn door alle 10 universiteiten aan DESAN geleverd en de verzending heeft dus in beide meetjaren volledig centraal plaatsgevonden. Evenals bij de HBO Monitor zijn in 2004 één elektronische aanbiedingsbrief (email) en daarna twee schriftelijke aanbiedingsbrieven verstuurd. In 2005 was er na de eerste verzending via email nog een email rappel zending alvorens de twee schriftelijke verzendrondes hebben plaatsgevonden. Vanwege de aan universiteiten gegeven responsgarantie is er in een aantal sectoren en voor een aantal universiteiten nog een telefonische belronde geweest in beide meetjaren. De responscijfers zijn ongeveer gelijk aan die van het HBO, in 2005 was de respons 47\%. Net zoals bij de andere opleidingsniveaus is het in het WO met de sector Landbouw die hoog scoort. Afgestudeerden met een opleiding uit de sector Recht en openbare orde hebben het minst vaak gerespondeerd.

5. Het ROA draagt zorg voor de uitvoering van de WO Monitor voor 10 van de 13 universiteiten die in landelijk verband meedoen met de monitor. Paragraaf 4.3 heeft betrekking op de dataverzameling van alleen deze 10 instellingen. 


\section{Datacleaning}

$\mathrm{Na}$ de dataverzameling voegt DESAN de verschillende bestanden samen en worden er enkele controles uitgevoerd alvorens de data naar ROA voor verdere datacleaning worden gestuurd. Deze controles hebben betrekking op: de aanwezigheid van dubbele cases in de data en gaten in de responsadministratie (zijn er groepen of scholen overgeslagen?) en de gecodeerde opleidingsvariabele. Daarnaast worden voor de HBO vragenlijsten de vraag over voltijd/deeltijd studievariant aangevuld met administratiegegevens indien de vraag niet is ingevuld door de respondent. Aan de hand van de gecodeerde landenvariabelen berekent DESAN tenslotte nog enkele variabelen die betrekking hebben op etniciteit en landenindelingen (bijvoorbeeld EU versus niet EU).

De datacleaning en dataverwerking die het ROA uitvoert na ontvangst van de bestanden van DESAN bestaat uit drie hoofdonderdelen;

- controle op variabelen en verwijzingsstructuren, dit wordt in de rest van dit hoofdstuk besproken;

- het aanmaken van samengestelde, zogenaamde 'nieuwe' variabelen, dit wordt in hoofdstuk 6 nader toegelicht;

- het wegen van de data, dit wordt in hoofdstuk 7 besproken.

De datacleaning van het ROA richt zich met name op het controleren van de vragenlijststructuur met betrekking tot verwijzingsvragen en inconsistenties tussen antwoorden van respondenten. Deze inconsistenties zijn onvermijdelijk omdat er altijd respondenten zijn die zich vergissen, vragen verkeerd begrijpen of vragen niet invullen.

\section{Algemene variabelencontrole}

Allereerst wordt gekeken of de variabelen de goede naam, het goede label, de goede value labels en het goede format hebben. Daarnaast kunnen er variabelen niet in de aangeleverde bestanden zitten of kunnen er extra variabelen in aanwezig zijn. Deze controle wordt gedaan met behulp van een variabelen database die bij de opmaak van de vragenlijsten door ROA bijgewerkt wordt. Deze variabelen database dient als basis voor de data-entry programma's en internetscripts en is ook in de verdere datacleaning een belangrijke informatiebron.

\section{Controle basisvariabelen}

Een aantal basisvariabelen zoals gevolgde opleiding, diplomabezit en afstudeerjaar worden gecontroleerd op validiteit. Naar aanleiding hiervan worden enkele eerder door DESAN aangemaakte hulpvariabelen over de afstudeerperiode en bruikbaarheid (afboekcodes) van cases bijgewerkt. 
ledere vragenlijst wordt gecontroleerd aan de hand van de ingebouwde verwijzingsstructuren. Vragen die men niet had hoeven invullen worden leeggemaakt. Doordat meer en meer gebruik gemaakt wordt van internetscripts worden heel veel verwijzingen automatisch doorgevoerd. Aan de hand van de verwijzingsstructuur wordt een onderscheid gemaakt tussen 'system' missing waarden en 'user' missing waarden. In beide gevallen is de variabele niet gevuld voor de desbetreffende case. System missing houdt in dat de variabele (vraag) niet relevant is. Zo hoeven personen zonder werk vragen over de huidige baan niet in te vullen. User missing (in het bestand altijd de waarde -9) houdt in dat de respondent de vraag wel had moeten invullen maar dit niet heeft gedaan. Zo zal bijvoorbeeld niet iedereen die betaald werk heeft zijn of haar inkomen willen invullen.

Voor het cleanen van verwijzingsvragen zijn vaste regels die voor alle vragenlijsten gehanteerd worden. Indien de respondent een antwoord heeft gegeven waar een verwijzing op van toepassing is dan hangt de cleaning van de verwijzingsvraag af van het aantal vervolgvragen dat niet ingevuld hoefde te worden. Als er drie of minder vragen zijn dan wordt de verwijzingsvraag zelf gecorrigeerd indien al deze vragen (toch) zijn ingevuld. Zijn er vier of meer vragen die volgens de verwijzing niet hadden hoeven te worden ingevuld dan wordt de verwijzingsvraag pas gecorrigeerd indien er minstens 3 van deze vragen (toch) een geldig antwoord hebben. Indien de respondent volgens zijn antwoord niet onder de verwijzing valt en de volgende vraag gewoon moet invullen worden deze op -9 (user missing) gezet indien hij de vragen (toch) niet ingevuld heeft. De verwijzingsvraag zelf wordt in dit laatste geval niet gecorrigeerd.

\section{Inhoudelijke variabelencontrole}

Naast de controle op format, naam en labels wordt gekeken of de variabelen in de databestanden gevuld zijn met toegestane, valide waardes. Bij gesloten vragen moeten de waardes van variabelen overeenkomen met de antwoordcategorieën die op de vragenlijst staan. Daarnaast wordt bij numerieke variabelen gecontroleerd op extreme en niet valide waarden. Extreme waarden worden tijdens de cleaning terug gezet naar user-missing (-9). Bij de vraag over de maatschappelijke positie (belangrijkste bezigheid op moment van enquêteren) worden de ingevulde antwoorden bij de 'anders'-categorie waar mogelijk teruggebracht naar een bestaande voorgecodeerde categorie.

Meerkeuzevragen worden in de data vastgehouden als dichotome variabelen, iedere antwoordcategorie is een aparte variabele. Hierbij staat de waarde 0 voor 'niet genoemd' en de waarde 1 voor 'wel genoemd'. De gehanteerde datacleaning houdt per vraag het volgende in: indien er geen enkele variabele gevuld is krijgen alle variabelen van deze vraag de waarde -9 (user-missing). Als er minimaal 1 variabele gevuld is (waarde 1) krijgen alle niet gekozen variabelen van deze vraag de waarde 0 en worden dus aangemerkt als 'niet genoemd'. 
Bij sommige vragen dient de respondent aanvullende informatie (numerieke informatie of tekst) te geven indien er voor een bepaalde antwoordcategorie gekozen is. Zo wordt bijvoorbeeld naar het aantal personen waar men leiding aan geeft gevraagd indien er 'ja' aangegeven is op de vraag of men leiding geeft. Dit soort vragen wordt gecontroleerd en gecorrigeerd op onderlinge consistentie.

\section{Arbeidsuren en inkomen}

In de vragenlijsten van het hoger onderwijs wordt onderscheid gemaakt tussen het aantal arbeidsuren in de reguliere werkweek en het aantal uren uit overwerk. Als het aantal uren van de reguliere werkweek ingevuld is en het aantal uren overwerk niet wordt het aantal uren overwerk op 0 gezet. Dit wordt gedaan omdat sommige respondenten geneigd zijn voor hen niet relevante vragen niet in te vullen. Als het aantal uren in de reguliere werkweek onbekend is en het aantal uren overwerk is wel ingevuld dan wordt het aantal uren in de reguliere werkweek gevuld met het aantal uren overwerk. Het aantal uren overwerk wordt vervolgens op 0 gezet. Eenzelfde procedure wordt gehanteerd voor de vraag over arbeidsuren in eventuele nevenfuncties. Bij de drie inkomensvragen in het hoger onderwijs worden eveneens, indien minsten één van de inkomens is ingevuld de andere variabelen gehercodeerd van missing naar 0 .

\section{Nieuwe variabelen}

$\mathrm{Na}$ het proces van datacleaning wordt een aantal nieuwe variabelen aangemaakt. Nieuwe variabelen zijn in het bestand te herkennen aan de ' $n$ _' notatie waarmee de variabelenaam begint. Deze variabelen worden gemaakt om het gebruiksgemak van de bestanden te vergroten en te zorgen voor continuïteit en vergelijkbaarheid tussen zowel de verschillende vragenlijsten als de verschillende meetjaren. Een nieuwe variabele kan om twee redenen worden gemaakt. Allereerst om (kleine) verschillen in vraagstelling tussen de onderlinge vragenlijsten op te heffen. Vanwege de verschillen in onderzoekspopulaties is bijvoorbeeld de vraagstelling met betrekking tot het volgen van vervolgonderwijs niet overal hetzelfde. Om echter toch aan te kunnen geven welke respondenten naar het vervolgonderwijs zijn gegaan wordt hiervoor één indicator berekend. Daarnaast zijn er nieuwe variabelen die niet op één maar op meerdere vragen, en dus meerdere variabelen van een vragenlijst gebaseerd zijn. Hierbij gaat het met name om variabelen die betrekking hebben op werkloosheid en beroepsbevolking en dergelijke. In de rest van dit hoofdstuk worden enkele van de belangrijkste nieuwe variabelen kort toegelicht.

\section{Baankenmerken}

- huidige functie aantal arbeidsuren (n_hau): in verband met extreme waarden wordt $0.5 \%$ van de bovengrens van deze variabele gehercodeerd naar -9 (user missing).

- bruto uurloon huidige functie (n_hbiu): de variabele is gebaseerd op het inkomen en de arbeidsuren van de huidige functie exclusief overwerk. In verband met extreme waarden wordt $0.5 \%$ van de ondergrens en $0.5 \%$ van de bovengrens op missing (-9) gezet. 
- volledige of deeltijd betrekking (n_hau33): Personen die meer dan 32 uur werken in een normale week, dus zonder overuren en uren van eventuele nevenfuncties hebben een voltijd betrekking.

- dienstverband (n_hdvb2): dienstverband huidige functie (zoals 'loondienst' en 'zelfstandige') .

- soort aanstelling ( $n \_$hasd): deze indicator geeft aan of de huidige aanstelling een tijdelijk of een vast karakter heeft.

- functie op eigen niveau (n_hnwg): de variabele geeft aan of de respondent een functie heeft die minimaal op zijn eigen niveau is of niet. Deze variabele wordt bepaald door het door de werkgever vereiste opleidingsniveau te vergelijken met het niveau van de gevolgde opleiding van de afgestudeerde.

- functie binnen eigen richting ( $n \_$horwg): indicator die aangeeft of iemand in zijn eigen/verwante richting werkt of in een andere (of geen specifieke) richting.

\section{Arbeidsmarktkenmerken}

- beroepsbevolking (n_berbv1, n_berbv2): iemand die 12 uur of meer werkt behoort tot de werkzame beroepsbevolking, iemand die niet of minder dan 12 uur werkt maar wel op zoek is naar (meer) betaald werk behoort tot de werkloze beroepsbevolking. Respondenten die aangegeven hebben zichzelf als student te zien worden niet meegenomen bij de berekening van de n_berbv2 variabele. Deze correctie is noodzakelijk vanwege de specifieke samenstelling van de onderzoekspopulatie. Van de populatie studeert een aanzienlijk deel verder en hebben er velen naast hun studie een bijbaantje van een aantal uren in de week. Het niet uitsluiten van deze groep zou leiden tot een vertekend beeld van de werkzame en werkloze beroepsbevolking. De variabele n_berbv2 wordt dan ook standaard in rapportages gebruikt.

- aanbieden op de arbeidsmarkt (n_aanb1, n_aanb2); de variabele geeft aan of iemand zich wel of niet aanbiedt op de arbeidsmarkt. Degenen die zich aanbieden behoren tot de beroepsbevolking (werkend of werkloos). Ook hier worden de 'studenten' bij de tweede variant van de variabele (n_aanb2) buiten beschouwing gelaten.

- intredewerkloosheid (n_wklipm): het aantal maanden dat men werkloos is geweest vanaf het moment van afstuderen tot het moment van het invullen van de enquête. Voor personen die niet werkloos geweest zijn wordt deze variabele op 0 maanden gezet.

\section{Gevolgde opleiding}

- sector van gevolgde opleiding (n_sector): indeling van de gevolgde opleidingen naar onderwijssector.

- sector en niveau van gevolgde opleiding (n_gokop2): indeling van de gevolgde opleidingen naar onderwijssector en onderwijsniveau. Het aantal sectoren kan per onderwijsniveau verschillen. 


\section{Vervolgonderwijs}

- $\quad$ sector en niveau van de vervolgopleiding (n_vokop2): indeling van de gevolgde vervolgopleidingen naar onderwijssector en onderwijsniveau. Het aantal sectoren kan per onderwijsniveau verschillen.

- $\quad$ niveau vervolgonderwijs (n_nivvvo): deze variabele geeft aan of de vervolgopleiding van een hoger niveau is dan de gevolgde, verlaten opleiding.

De hier genoemde nieuwe variabelen vormen slechts een klein deel van het totale aantal nieuwe variabelen. Een volledig overzicht van de nieuwe variabelen is te vinden in het bij de bestanden behorende documentatiesysteem.

\section{Weging}

\subsection{VO- en BVE Monitor}

\section{VO Monitor}

Bij de VO Monitor hangt de grootte en de spreiding van de steekproef af van de deelname van de onderwijsinstellingen. Hierdoor kan er een ongelijke spreiding naar opleiding en regio ontstaan. Ook naar het kenmerk 'geslacht' zullen de respondenten afwijken van de landelijke cijfers. Zelfs wanneer door grote schooldeelname de steekproef wat betreft de verdeling mannen en vrouwen representatief is voor de landelijke populatie zal het uiteindelijke databestand toch een scheve verdeling op dit kenmerk laten zien. Dit wordt veroorzaakt doordat de respons bij vrouwen groter is dan bij mannen bij dit soort onderzoeken. Om bovengenoemde redenen vormen de data dus geen landelijke weergave van de doelgroep. Om toch betrouwbare landelijke cijfers te kunnen presenteren wordt een weging uitgevoerd waarbij de data gewogen worden naar de landelijke populatie aantallen.

De weging van de AVO en VMBO respondenten vindt plaats op een drietal kenmerken, namelijk opleiding, regio en geslacht. De weging naar opleiding vindt hierbij plaats op het niveau van CREBO codes. Een CREBO code is een unieke opleidingscode die gebruikt wordt in de Integrale Leerling Telling (ILT). Alhoewel de voor de weging gebruikte populatiecijfers afkomstig zijn van het CBS vormen de ILT data eigenlijk de basis voor de landelijke aantallen. De cijfers voor het wegen van de VMBO landbouw sector zijn afkomstig van STOAS Onderzoek te Wageningen. In hoofdstuk 1 (tabel 1.1) staan de uiteindelijke populatiecijfers voor de meetjaren 2004 en 2005 van de schoolverlaters uit het VO en het VMBO. In tabel 7.1 staat een kort overzicht met betrekking tot de weging van de VO-, BVE- en HBO Monitor. 
Tabel 7.1

Weging VO -, BVE - en HBO Monitor ${ }^{1)}$

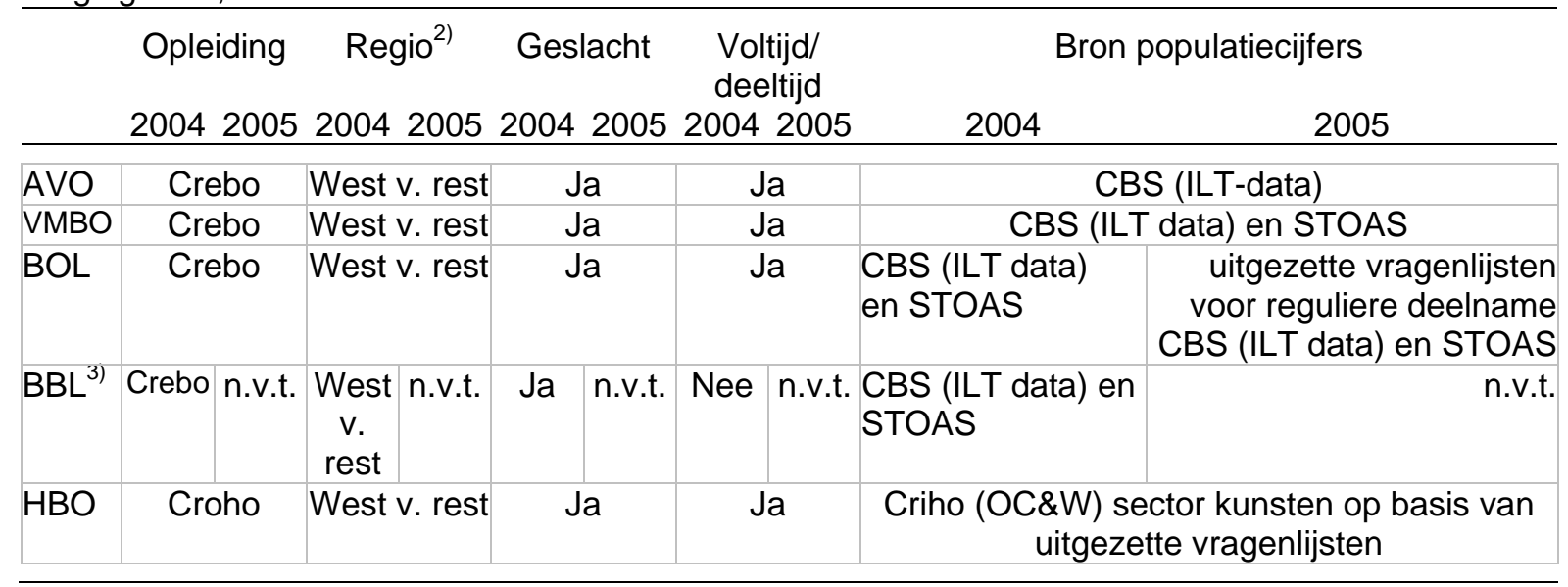

\footnotetext{
1) Alleen gediplomeerde respondenten worden gewogen

2) Regio West zijn de provincies Utrecht, Noord Holland, Zuid Holland en Zeeland

3) Vanwege de te lage aantallen zijn de BBL data in 2005 niet gewogen
}

\section{BVE Monitor 2004}

In 2004 zijn de data van de BOL en BBL afgestudeerden gewogen naar opleiding, regio en geslacht. Evenals bij de VO Monitor is hierbij gewogen naar de CREBO opleidingscodes. De ILT populatiecijfers zijn afkomstig van het CBS, de cijfers voor de sector landbouw van STOAS Onderzoek. De wegingprocedure van de BVE Monitor was in meetjaar 2004 dus identiek aan die van de VO Monitor.

\section{BVE Monitor 2005}

Ten opzichte van meetjaar 2004 zijn er twee belangrijke wijzigingen in de weging van de BOL en BBL afgestudeerden. Ten eerste zijn de BBL data niet gewogen. Door de te lage aantallen waren er te weinig opleidingen en dus per definitie te weinig opleidingen per regio hetgeen het wegen naar landelijke representatieve cijfers niet mogelijk maakte. De weging van de BOL data daarentegen is enigszins vereenvoudigd doordat er door de steekproeftrekking er per definitie sprake is van een landelijk representatieve steekproef. De in het bestand aanwezige gediplomeerde BOL respondenten kunnen hierdoor worden gewogen met behulp van één 'landelijke' weegfactor voor alle cases (populatie/aantal respondenten). Voor de populatiecijfers zijn de ILT data afkomstig van het CBS gebruikt. Op deze landelijke weegfactor zijn echter drie uitzonderingen gemaakt:

- de respons die het gevolg is van reguliere deelname van scholen is opgehoogd naar het totale, voor deze scholen uitgezette aantal vragenlijsten. Dit totale aantal van deze scholen is afgetrokken van de landelijke populatiecijfers bij de bepaling van de landelijke weegfactor;

- de sector BOL landbouw is apart gewogen waarbij de sector als geheel met één weegfactor is opgehoogd naar de populatie aantallen zoals die door STOAS aange- 
leverd worden. De populatie van deze sector is vervolgens afgetrokken van de landelijke populatiecijfers bij de bepaling van de landelijke weegfactor;

- door de deelname van de gemeente Rotterdam is de steekproef uit deze regio eveneens apart behandeld. Deze cases zijn met één weegfactor opgehoogd naar het totale populatie aantal behorende bij de in deze regio deelnemende scholen. Ook dit populatie aantal is in mindering gebracht op de populatiecijfers voor het bepalen van de 'landelijke' weegfactor.

\subsection{HBO Monitor}

In tegenstelling tot de VO en BVE Monitoren worden de HBO data naar vier kenmerken gewogen. Behalve naar opleiding (Croho), regio en geslacht wordt er namelijk ook rekening gehouden met de voltijd/deeltijd component van de gevolgde opleiding. Binnen het hoger onderwijs is er een onderscheid tussen de reguliere voltijd opleidingen en opleidingen die slechts een deel van de week gevolgd/aangeboden worden. Hierbij gaat het vaak om opleidingen die in de avonduren gegeven worden of opleidingen waarbij slechts 1 dag per week onderwijs gegeven wordt. De afgestudeerden van beide varianten verschillen wat betreft arbeidsmarktachtergrond en leeftijd aanzienlijk van elkaar. Deeltijd studenten zijn vaak ouder dan de reguliere voltijd studenten en hebben ook meestal reeds enige jaren werkervaring. Daarom wordt deze vierde dimensie bij de weging van de respondenten meegenomen. De populatiecijfers zijn afkomstig van het Centraal Register Inschrijvingen Hoger Onderwijs (Criho) van het Ministerie van OC\&W. Deze cijfers bevatten per opleidingsvariant het aantal gediplomeerde mannen en vrouwen per hogeschool en dus per regio. Voor opleidingen uit de sector kunst wordt het totale aantal uitgezette vragenlijsten gebruikt als populatie cijfer omdat de Criho cijfers niet tot betrouwbare aantallen leidde.

\subsection{WO Monitor}

De data van de WO Monitor worden niet gewogen maar enkel opgehoogd naar het landelijke populatiecijfer met 1 weegfactor voor alle cases. Dit omdat er bij de WO Monitor geen sprake is van een aselecte steekproef en de gehele populatie in de steekproef zit. De data worden dan ook opgehoogd naar het landelijk aantal uitgezette vragenlijsten.

\subsection{Controle op weegfactoren}

Voor het wegen van de data wordt op basis van de weegkenmerken een steekproefmatrix gemaakt. Vervolgens wordt de steekproefmatrix vergeleken met de populatiematrix. Hierbij kunnen twee soorten problemen aan het licht komen:

- het aantal in de steekproefmatrix is groter dan het aantal in de populatiematrix;

- er is geen aantal in de populatiematrix.

In beide gevallen wordt het populatie aantal gebruikt van het jaar ervoor. Indien dit populatie aantal ook niet toereikend of niet bekend is wordt het totale aantal benaderde afgestudeerden als populatie aantal gebruikt. Aangezien echter voor de non respondenten het 
kenmerk geslacht onbekend is vindt de weging plaats op de kenmerken opleiding, regio en eventueel voltijd/deeltijd.

$\mathrm{Na}$ het bepalen van de weegfactoren worden deze gecontroleerd op consistentie en waarschijnlijkheid. Wanneer de populatie van het jaar ervoor minstens twee keer zo groot was wordt uitgezocht wat hier de oorzaak van is. Tot op heden werd dit veroorzaakt door kleine aantallen of nieuwe opleidingen. Daarnaast moet de uiteindelijke weegfactor kleiner zijn dan drie maal de weegfactor van de onderwijssoort als totaal. Is dit wel het geval dan wordt één weegkenmerk buiten beschouwing gelaten en vervolgens de controleregel opnieuw bekeken. Genoemde controle vindt alleen plaats in gevallen waar het steekproefaantal kleiner is dan 50. In een aantal gevallen wordt de weegfactor 1 toegekend namelijk wanneer de opleidingscode niet specifiek genoeg is of het kenmerk geslacht onbekend is. 